\title{
Wages, Skills, and Integration in Poland, Hungary and the Czech Republic: an Industry-level Analysis
}

\author{
Rosario Crinò $^{1,2}$ \\ ${ }^{1}$ Istituto di Scienze Economiche Aziendali e Statistiche, Università degli Studi \\ di Milano, Milan, Italy \\ ${ }^{2}$ Centro di Ricerca sui Processi di Innovazione e Internazionalizzazione, \\ Università Bocconi, Milan, Italy \\ (E-mail: rosario.crino@unibocconi.it)
}

\begin{abstract}
This paper analyzes the manufacturing sector of Poland, Hungary, and the Czech Republic between 1993 and 2001 and provides a set of stylized facts regarding the changes occurring in the skill composition of the workforce and in the earning structure by skills, on one hand, and in trade flows and foreign presence through direct investment, on the other hand. All three countries have experienced sharp increases in earning inequality which have concerned almost all manufacturing industries; relative skilled employment has, instead, decreased in almost all Hungarian and Czech industrial branches, while showing the opposite trend in the Polish counterparts. At the same time, the three countries have reoriented and expanded their trade flows and modified the merchandise composition of both exports and imports in favour of high-tech and capital-intensive sectors and against more traditional industries. Foreign direct investment has acquired progressively more importance in the three economies and the high-tech sector - as well as chemicals and machineries - has significantly gained relevance on total stocks. Correlation analysis comes in favour of a prevalently vertical nature of multinational enterprises; moreover, trade flows are in general negatively correlated with relative wages and employment, whereas the sign of the relation between foreign direct investments and earning inequality is clearly positive in Poland only.
\end{abstract}

Keywords: wage; skill; international integration; correlation.

JEL classification: J31, F16.

For all the Central and Eastern European countries (CEECs), the fall of the Berlin wall metaphorically represents the end of the socialist experience and the beginning of the transition from the command to the market. Since then, widespread and pervasive reforms have affected all the economies in the 
region and modified their legal, social, economic, and bureaucratic systems, making them much more similar to modern market economies; fifteen years later, the success of these reforms has led the eight most outstanding CEECs to the EU membership, finally obtained on May 1, 2004.

Since the end of the 1980s, a large stream of literature has developed on several crucial aspects of the transition, such as the optimal speed of the process (Aghion and Blanchard 1994), the determinants of the recession in the early 1990s and the reasons for the different recovering paths experienced within the region (Blanchard and Kremer 1993, Rosati 1994, Roland and Verdier 1999), the labour market effects of transition (Commander et al. 1992, Boeri 2000, Boeri and Terrel 2002, Campos and Coricelli 2002, Commander and Kollo 2004), and, more recently, the opportunities offered by the ongoing EU enlargement (Boeri and Brucker 2002, Facchini and Segnana 2003). Other studies have concentrated specifically on the manufacturing sector, analyzing the structural changes in industrial production (Urban 2000), the patterns of technological activity (Kneel 2000) and the occurrence and effects of increasing international integration in the form of both higher trade openness (Egger and Stehrer 2003, De Benedictis and Tajoli 2003) and higher attitude towards direct penetration by foreign investors (Barrel and Holland 2000, Hunya 2000, Resmini 2000, Bedi and Cieslik 2002, Bruno et al. 2004).

Within the latter group of studies, this paper focuses on the secondary sector of Poland, Hungary, and the Czech Republic during the period of 1993-2001; it provides a set of stylized facts concerning two different but related issues: on the labour market side, it analyzes the changes in the skill composition of the workforce and the corresponding modification in the earning structure by skills; on the international integration side, it describes the changes occurring across industries both in trade flows and in foreign presence through direct investments (FDI). I exploit an industry-year panel consisting of fourteen NACE Rev.2 manufacturing industries and containing information on employment and gross wages for production (unskilled) and nonproduction (skilled) workers, as gathered from each country's statistical yearbooks, exports and imports of final goods (source: OECD, "STAN Database for Industrial Analysis") and inward FDI stocks (source: OECD, "International Direct Investment Statistics'). ${ }^{1}$ The study is conducted from an industry-level perspective and aims at analyzing the two issues not just by looking at the aggregate manufacturing sector but, instead, by concentrating on the developments which occurred within and across its constituent branches.

The rest of the paper is organized as follows: first I deal with the labour market side and focus on the skill composition of the workforce and on the earning structure by skills in particular; then the international integration process undertaken by the three countries is described with specific attention to trade flows and FDI; finally, the relationship between the two issues 
analyzed in previous sections is characterized by reporting the results from correlation analysis.

\section{Employment, skills, and wage inequality}

Although the tertiary sector of the three countries has become progressively more important in terms of total labour force employed during the 1990s, the secondary sector still accounts today for more than $29 \%$ of total employment in Poland, for 33\% in Hungary, and for $40 \%$ in the Czech Republic (European Commission 2004); these percentages have been even higher in the past ten years and this, therefore, makes worth analyzing the developments that have occurred in the industrial sector of the three economies since 1993.

In general, the number of employees in manufacturing has slightly grown in Poland between 1994 and 2001, the highest increases being registered in 1995 and 1996; in contrast, manufacturing employment has shrunk in Hungary and in the Czech Republic, mainly in the first half of the decade. ${ }^{2}$

As to each branch's contribution to the aggregate pattern in manufacturing employment, Table 1 shows that the share of food and tobacco has significantly declined in Hungary, while rising slightly in the Czech Republic and

Table 1. Industry shares of total manufacturing employment (calculations based on the countries' statistical yearbooks)

\begin{tabular}{|c|c|c|c|c|c|c|c|c|c|}
\hline \multirow[t]{2}{*}{ Sector } & \multicolumn{3}{|c|}{ Hungary } & \multicolumn{3}{|c|}{ Poland } & \multicolumn{3}{|c|}{ Czech Republic } \\
\hline & 1993 & 1997 & 2001 & 1994 & 1997 & 2001 & 1993 & 1997 & 2001 \\
\hline $\begin{array}{l}\text { Food products, } \\
\text { beverages, tobacco }\end{array}$ & 21 & 18 & 16 & 16 & 18 & 19 & 10 & 12 & 11 \\
\hline Textiles, textile products & 14 & 15 & 12 & 14 & 14 & 12 & 11 & 10 & 9 \\
\hline Leather, leather products & 4 & 4 & 3 & 3 & 3 & 2 & 3 & 2 & 2 \\
\hline Wood, wood products & 2 & 2 & 3 & 3 & 4 & 4 & 2 & 3 & 3 \\
\hline $\begin{array}{l}\text { Pulp, paper, paper } \\
\text { products }\end{array}$ & 5 & 4 & 4 & 3 & 4 & 5 & 3 & 4 & 4 \\
\hline Coke, refined petroleum & 3 & 2 & 2 & 1 & 1 & 1 & 1 & 0 & 0 \\
\hline $\begin{array}{l}\text { Chemicals, chemical } \\
\text { products }\end{array}$ & 7 & 6 & 2 & 6 & 5 & 5 & 4 & 4 & 4 \\
\hline Rubber, plastic products & 3 & 4 & 5 & 2 & 4 & 5 & 2 & 4 & 5 \\
\hline $\begin{array}{l}\text { Other nonmetallic } \\
\text { mineral products }\end{array}$ & 5 & 5 & 4 & 6 & 6 & 6 & 6 & 7 & 7 \\
\hline $\begin{array}{l}\text { Basic metals, fabricated } \\
\text { metal products }\end{array}$ & 11 & 10 & 11 & 12 & 12 & 11 & 17 & 17 & 16 \\
\hline Machinery, equipments n.e.c. & 9 & 8 & 8 & 13 & 10 & 9 & 17 & 14 & 12 \\
\hline $\begin{array}{l}\text { Electrical, optical } \\
\text { equipments }\end{array}$ & 9 & 13 & 20 & 7 & 7 & 7 & 8 & 10 & 13 \\
\hline Transport equipments & 4 & 5 & 6 & 10 & 8 & 8 & 10 & 8 & 10 \\
\hline Manufacturing n.e.c. & 3 & 4 & 4 & 4 & 4 & 6 & 6 & 5 & 4 \\
\hline
\end{tabular}


more prominently in Poland; in every country, the relative importance of textiles has decreased, similarly to what has happened to chemicals, machineries, and nonmetallic mineral products; at the same time, labour has apparently reallocated towards high-tech industries such as electric and optical equipments and transportation equipments in Hungary and in the Czech Republic, and towards more traditional sectors such as wood products, paper and printing, and rubber and plastic products in Poland.

Decomposing the workforce between skilled (nonproduction) and unskilled (production) workers completes the description of the trends in aggregate manufacturing employment. What is particularly interesting to note is that the labour force employed in manufacturing has become progressively more skilled in Poland, but so neither in Hungary nor in the Czech Republic. In fact, the ratio of skilled to unskilled labour has risen from 0.28 to 0.31 in Poland, while declining from 0.29 to 0.25 in Hungary and from 0.38 to 0.33 in the Czech Republic. The latter trends are the result of a faster decline in skilled employment in the first half of the 1990s in Hungary and in the second half of that decade in the Czech Republic; for Poland, the trend is attributable to a much slower decrease in the number of nonproduction workers at the end of the decade (Fig. 1).

Similarly to what has been observed in other industrialized and industrializing countries (Lawrence and Slaughter 1993, Feenstra and Hanson 1997, Blonigen and Slaughter 2000, Pavcnik 2003), the posttransition period has been characterized by a marked rise in the skill premium also in the three CEECs; indeed, the ratio of skilled to unskilled wage (skill premium) has increased from 1.41 to 1.80 in Poland, from 1.94 to 2.29 in Hungary, and from 1.4 to 1.81 in the
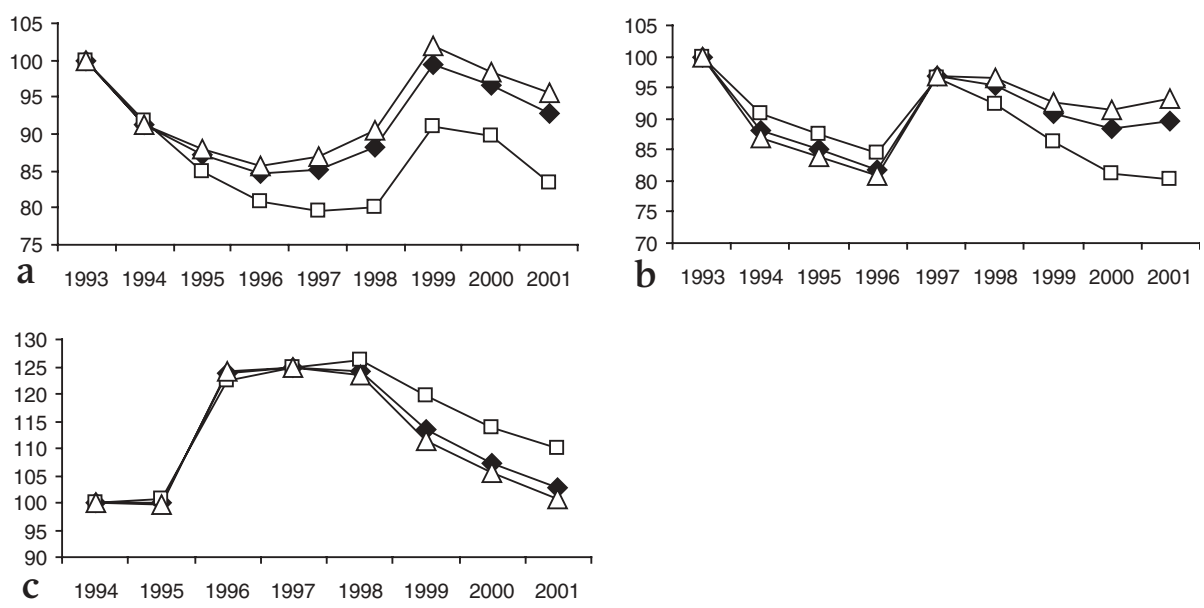

Fig. 1. Trends in skilled $(\square)$, unskilled $(\triangle)$, and average $(\diamond)$ manufacturing employment for Hungary (a), Czech Republic (b), and Poland (c). Calculations based on the countries' statistical yearbooks. Base year, 1993 for Hungary and Czech Republic, 1994 for Poland 

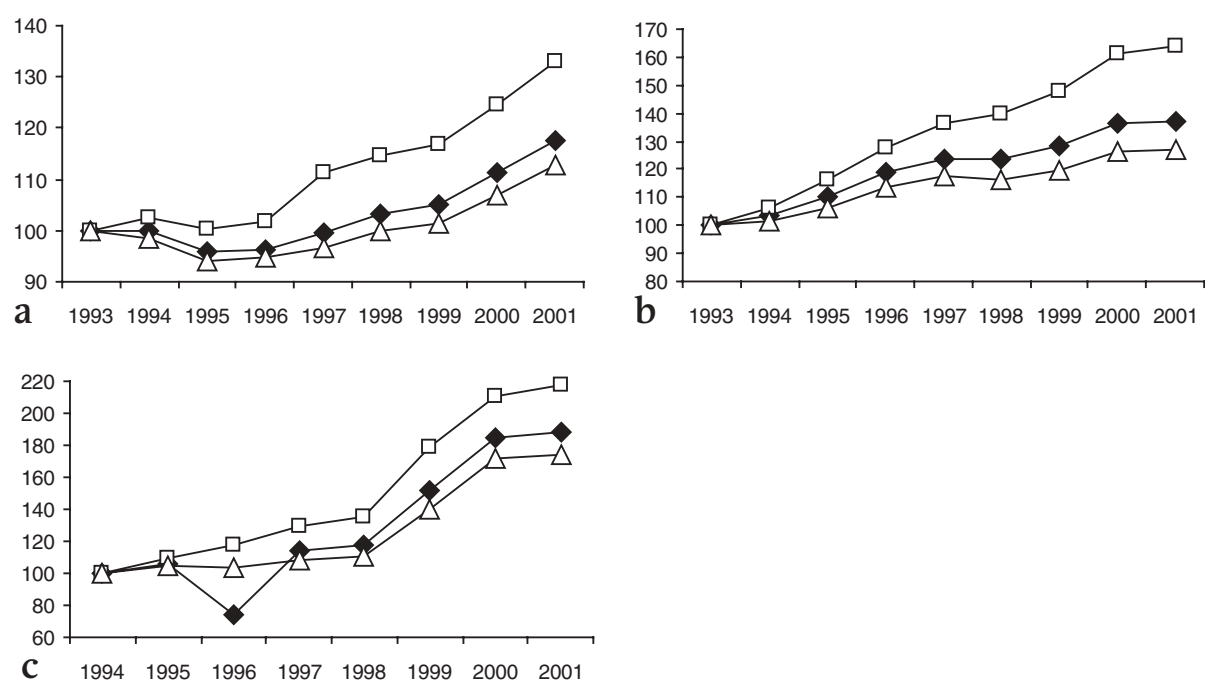

Fig. 2. Trends in skilled $(\square)$, unskilled $(\triangle)$, and average $(\bullet$ ) manufacturing wages for Hungary (a), Czech Republic (b), and Poland (c). Calculations based on the countries' statistical yearbooks. Base year, 1993 for Hungary and Czech Republic, 1994 for Poland

Czech Republic. There is a growing debate nowadays on the possible causes of this phenomenon in transition economies (Egger and Stehrer 2003, Bruno et al. 2004) and no clear consensus has been reached insofar. What is certain, however, is that the documented growth in wage differentials - resulting from a faster increase in the skilled wage relative to the unskilled and average wages (Fig. 2) - has been accompanied by a decline rather than an increase in the relative demand for skilled labour, as emphasized before; this is true at least for Hungary and for the Czech Republic and conflicts with the paths observed in other developed and developing countries.

If the shares of skilled labour in total manufacturing wage bill (WSH) and employment (ESH) are used in place of the ratios between nonproduction and production wages and employment, the picture does not change at all; in fact, while WSH has risen in all countries (4.9\% in Poland, 1.04\% in Hungary, and $3 \%$ in the Czech Republic), ESH has increased only in the Polish manufacturing sector (1.49\%) and, in contrast, has declined in Hungary (2.24\%) and in the Czech Republic (3.47\%). Changes in both shares may occur along two dimensions: between industries and within industry. The former relates to changes implied by the reallocation of the workforce towards industries with different skill intensity; the latter captures those changes which are caused by variations in the proportion of nonproduction workers within each industry. Following Berman et al. (1994), the overall change in the skilled-labour shares of total wage bill and employment can be decomposed into the two dimensions according to 


$$
\Delta S_{S}=\sum_{j=1}^{N} \Delta S_{j} \overline{P_{S j}}+\sum_{j=1}^{N} \Delta P_{S j} \overline{S_{j}} \quad \text { for } j=1, \ldots, N,
$$

where $S_{S}$ is the skilled-labour share of total employment (wage bill) in manufacturing, $P_{S j}$ is the skilled-labour share of employment (wage bill) in industry $j, S_{j}$ is the share of industry $j$ in total manufacturing employment (wage bill), $\overline{P_{S j}}$ and $\overline{S_{j}}$ are time averages of the corresponding variables; the first term on the right-hand side measures the variations between industries, whereas the second keeps track of the changes which occurred within an industry. Results reported in Table 2 show that consistent with what was observed for other developed (Berman et al. 1994) and developing countries (Pavcnik 2003), variations in both shares mainly occurred within industry rather than between industries in Poland, Hungary, and the Czech Republic.

Motivated by this evidence, I will now turn to analyze branch by branch how skill intensity of production and earning inequality have evolved between 1993 and 2001.

Starting from the employment side, Fig. 3a shows that the overall decline in relative skilled-labour demand in the Hungarian secondary sector has been driven by a widespread reduction in the skill ratio in all industrial branches ${ }^{3}$ but for food and tobacco - where the indicator has risen by $3 \%$-, paper, printing, and publishing, coke and petroleum products, and chemicals. In the last three industries, skill intensity of production has actually significantly increased (8\%, 20\%, and 24\%, respectively).

Relevant similarities may be found between the Hungarian and the Czech case (Fig. 3b). In both, in fact, the indicator has risen for food and tobacco (3\%), paper, printing, and publishing (4\%), coke and petroleum products (23\%), and chemicals (8\%); the only two relevant differences, therefore, are due to the fact that the ratio of skilled to unskilled employment has experienced increases (4\%) in the rubber and plastic industry and marked decreases in the metallurgic sector (11\%) in the Czech Republic but not in Hungary.

Also in Poland (Fig. 3c), finally, the rise in relative skilled employment has

Table 2. Decomposition of the change in the skilled-labour shares of total employment and total wage bill (calculations based on the countries' statistical yearbooks)

\begin{tabular}{|c|c|c|c|c|c|c|}
\hline \multirow[t]{2}{*}{ Country } & \multicolumn{3}{|c|}{$\%$ Change of employment } & \multicolumn{3}{|c|}{$\%$ Change of wage bill } \\
\hline & $\begin{array}{l}\text { Between } \\
\text { industries }\end{array}$ & $\begin{array}{l}\text { Within } \\
\text { industry }\end{array}$ & Total & $\begin{array}{l}\text { Between } \\
\text { industries }\end{array}$ & $\begin{array}{l}\text { Within } \\
\text { industry }\end{array}$ & Total \\
\hline Poland (1994-2001) & -0.065 & 1.564 & 1.49 & -3.37 & 8.28 & 4.91 \\
\hline Hungary (1993-2001) & -0.74 & -1.50 & -2.24 & -0.47 & 1.51 & 1.04 \\
\hline Czech Republic (1993-2001) & -0.80 & -2.67 & -3.47 & 0.60 & 2.40 & 3.00 \\
\hline
\end{tabular}



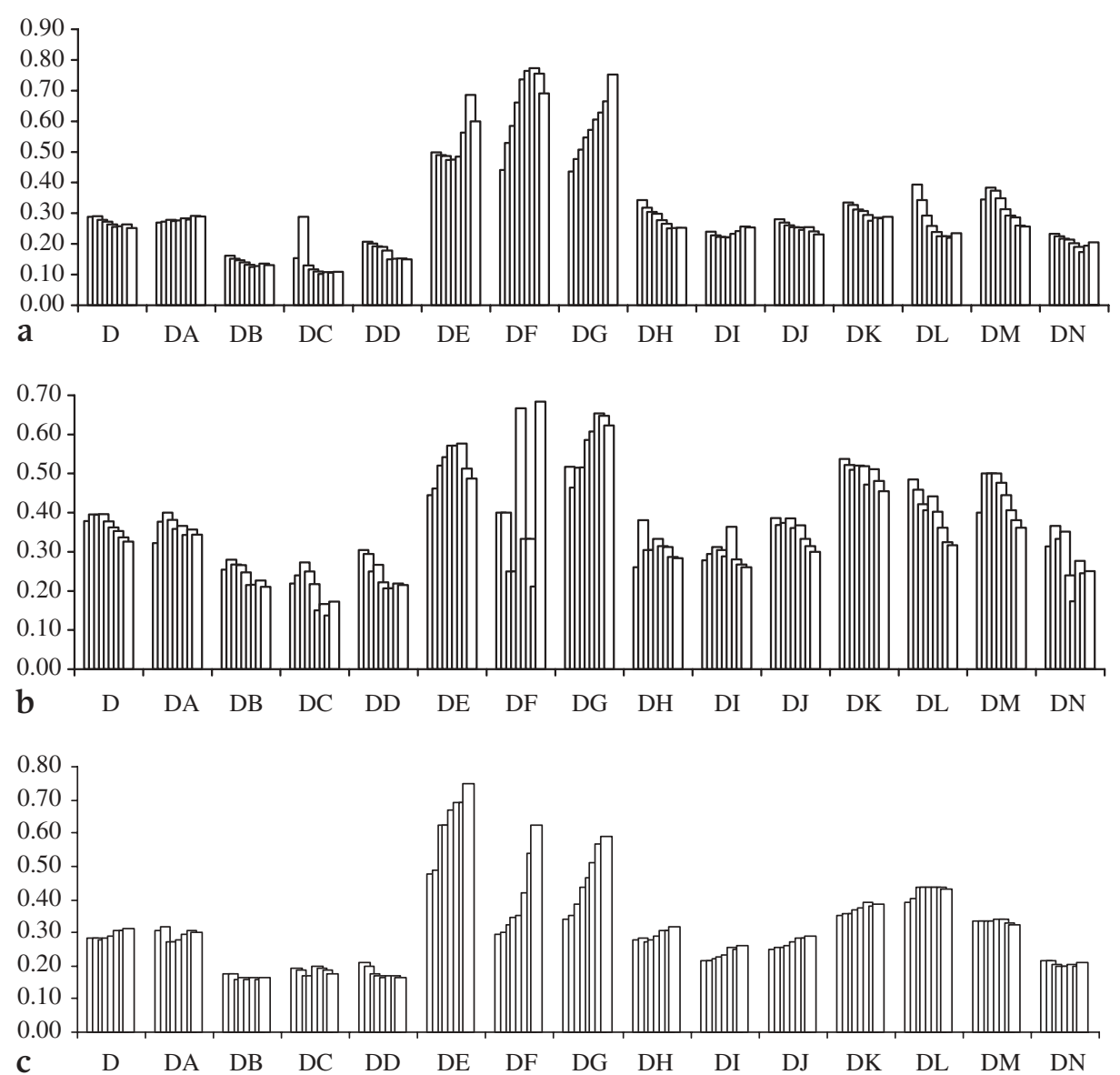

Fig. 3. Industry-level trends in the ratio of the numbers of nonproduction and production workers: a Hungary, b Czech Republic, c Poland. Calculations based on the countries' statistical yearbooks. D, manufacturing; DA, food products, beverages, and tobacco; DB, textiles and textile products; DC, leather and leather products; DD, wood and wood products; DE, pulp, paper, and paper products; DF, coke and refined petroleum; DG, chemicals and chemical products; DH, rubber and plastic products; DI, other nonmetallic mineral products; DJ, basic metals and fabricated metal products; DK, machinery and equipments not elsewhere classified; DL, electrical and optical equipments; DM, transport equipments; DN, manufacturing not elsewhere classified

been driven by dramatic increases in sectors which coincide with those driving the same phenomenon in the Czech Republic and in Hungary: paper, printing, and publishing (20\%), coke and petroleum products (33\%), and chemicals (24\%); however, the indicator has registered upsurges - although less strong - also for nonmetallic mineral products (8\%), the metallurgic sector (7\%), rubber and plastic products (6\%), machineries (4\%), and electric and optical equipments (4\%). On the other hand, different from the trend in the other two countries, the indicator has fallen for food and tobacco (1\%). ${ }^{4}$ 
As a further step, I have divided industries between high-skill-intensive and low-skill-intensive by comparing their skill ratio with the manufacturing average, and then individuated those that have switched their factor intensity during the period under consideration. ${ }^{5}$ Once again, Hungary and the Czech Republic show very similar behaviours. In both countries, in fact, food and tobacco have experienced a significant change in the skill intensity of production, as is evident from the fact that while in the first part of the decade the sector belonged to the low-skill-intensive group, it is now classifiable among the high-skill-intensive industries; in contrast, the sector of electric and optical equipments is more unskilled-labour-intensive today than it was at the beginning of the decade and than the manufacturing sector as a whole. Peculiarities however emerge from the pattern of the Czech metallurgic sector, which has become progressively more unskilled-labour intensive, and of the Hungarian sector of nonmetallic mineral products, which has recently shown a change in its production techniques in favour of a more intensive adoption of skilled workers. The paper, printing, and publishing sector, petroleum industry, and chemicals have been the highest skilled-labourintensive activities at the beginning of the 1990s and still maintain this position; for the unskilled-labour-intensive sectors, both countries show a relevant presence of traditional productions such as leather, textiles, and wood both at the beginning and at the end of the decade.

For Poland, the main difference with respect to the other two economies is due to the behaviour of the food and tobacco sector, whose production had already become more unskilled-labour-intensive in the first half of the 1990s. Relevant modifications in the factor intensity of production are also evident for rubber and plastic products, whose sector has been adopting relatively more skilled workers in later years.

I will now turn to the industry-level analysis of relative wages. For the sake of clarity, it will strictly follow the same steps as the employment analysis. Therefore, I begin by considering the branch-by-branch evolution of the skill premium (Fig. 4).

As evident, the picture is much clearer than it was for the employment, as the documented large increase in the ratio of skilled to unskilled wage at the aggregate manufacturing level has been driven by much more pervasive upsurges across all sectors in the three countries. In Poland and in the Czech Republic, indeed, all branches have been rewarding their nonproduction workers progressively more than the production employees, the only exceptions being the sectors of coke and petroleum and of rubber and plastic products. Poland, the largest skill-premium increases have occurred in the sectors of food and tobacco (17\%), paper, printing and publishing (12\%), rubber and plastic products (11\%), nonmetallic mineral products (13\%), and electric and optical equipments (16\%), while in all of other industries the wage gap has deepened by slightly less than $10 \%$. In the Czech Republic, the 

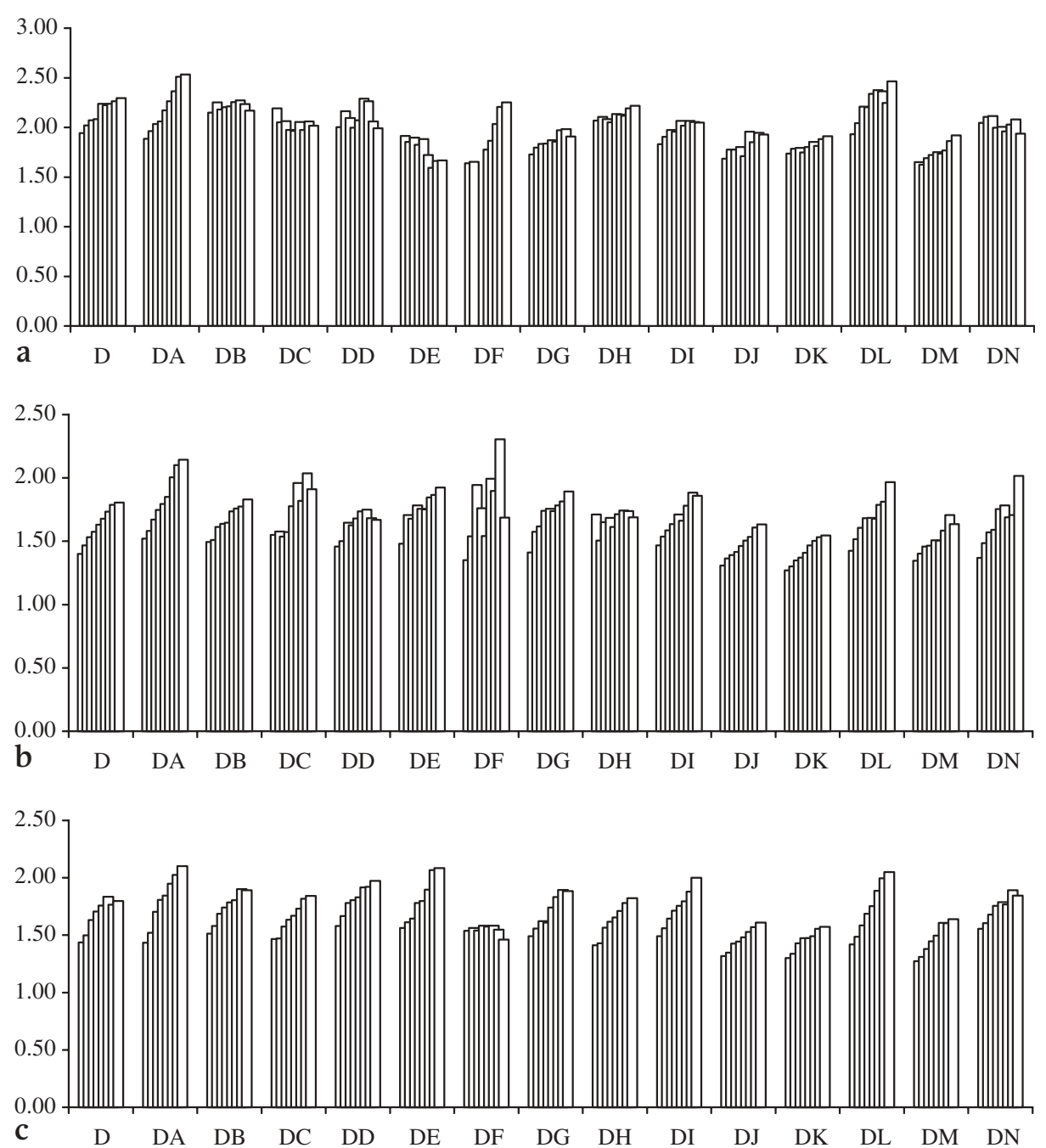

Fig. 4. Industry-level trends in ratio of nonproduction to production wages: a Hungary, $\mathbf{b}$ Czech Republic, c Poland. Calculations based on the countries' statistical yearbooks. D, manufacturing; DA, food products, beverages, and tobacco; DB, textiles and textile products; DC, leather and leather products; DD, wood and wood products; DE, pulp, paper, and paper products; DF, coke and refined petroleum; DG, chemicals and chemical products; DH, rubber and plastic products; DI, other nonmetallic mineral products; DJ, basic metals and fabricated metal products; DK, machinery and equipments not elsewhere classified; DL, electrical and optical equipments; DM, transport equipments; DN, manufacturing not elsewhere classified

skill premium has risen significantly (more than 10\%) in the sectors of food and tobacco (15\%), paper, printing, and publishing (11\%), chemicals (13\%), and electric and optical equipments (14\%). In Hungary, although rising in all industries but in the leather and leather products (-4\%), the relative skilled 
wage has experienced the least dramatic increases, growing on average by less than 7\% and experiencing 2-digit growth rates only in the sectors of food and tobacco (13\%), coke and petroleum (14\%), and electric and optical equipments (11\%).

In the attempt to benefit from a finer measure of wage inequality, the skilled-labour share of the total wage bill is usually considered a more complete indicator than the skill premium, since it simultaneously keeps track of both the relevant dimensions: relative employment and relative wages. In our case, it reveals that the worst increase in earning disparities has been experienced for food and tobacco and for chemicals, where the indicator has risen by $8.6 \%$ and $7 \%$ in Hungary, by $9.5 \%$ and $13.7 \%$ in the Czech Republic, and by $8 \%$ and $14.45 \%$ in Poland. Consistently with the previous facts, the skilledlabour share of total wage bill has increased also in the remaining Polish manufacturing sectors and in all the other Czech industrial branches but in the metallurgic; however, it has declined in almost all the remaining Hungarian industries. This evidence suggests that the increase in wage inequality has been worse and much more widespread in the Polish and in the Czech secondary sector than in the Hungarian one, where the bulk of the overall rise has been faced by the food and chemical industries alone.

\section{International integration}

\section{The new geographic and industrial composition of trade flows}

Before the end of the socialist experience, the participation in the COMECON rigidly determined the geographic and industrial composition of exports and imports in Central and Eastern Europe: direction and structure of trade flows were centrally imposed in all countries and comparative advantages were generally given scarce attention in favour of political considerations in the organization of trade networks among the formerly communist economies. It should not surprise at all, therefore, that the geographic structure of both exports and imports has experienced strong modifications in the three countries since the very beginning of the transition. In particular, the EU-15 has become the primary trading partner, accounting today for more than $70 \%$ of both exports and imports; intraregional trade has significantly lost ground after the fall of the COMECON, and today the shares of total Polish, Hungarian, and Czech trade flows accounted for by other CEECs are no higher than $20 \%$. Finally, Asian countries appear nowadays much more involved in trade relations with the three economies, even though their relative weights on total exports and imports still remain limited compared with those of the EU and of the other CEECs (UNCTAD 2002a).

Along with the marked geographic reorientation, trade flows have also experienced significant changes in their industrial composition during the 
transition process. Table 3, indeed, reveals that the major changes have concerned the export rather than the import structure and have been stronger in Poland and Hungary. In these countries, the food industry, the textiles and the metallurgic sector altogether accounted for almost $40 \%$ of total exports in 1993; moreover, an additional $25 \%$ was due at that time to chemicals and electrical equipments in Hungary, whereas a 14\% share was represented by transport equipments in Poland.

Today, exports are much more concentrated: electrical equipment and transport equipment account for more than half of the overall manufacturing figure in Hungary, and for more than a third in Poland. In the Czech Republic, the industrial composition of exports has evolved much less dramatically and, indeed, the metallurgic sector, machineries, and transport equipment account nowadays for more than $40 \%$ of manufacturing flows as they did in 1993; nonetheless, the sharp decrease in the share of chemicals and the significant increase in that of electrical equipments should not be neglected when comparing the export structure at the beginning of the decade with that at the end. For imports, two points have to be stressed: first, as anticipated, changes have been much less evident than in the export case; second, three sectors have accounted for more than $40 \%$ of manufacturing flows both in 1993 and in 2001: chemicals, machineries, and electrical equipments. Apart from these regularities, the similarity between Hungary's and Poland's structure both at the beginning and at the end of the period emerges once again clearly, and so does the strong role played by the Czech metallurgic industry over the entire decade.

Thus far, the discussion has shown how the trade structures of the three countries look today relative to 1993 and how they have changed during the 1990s; nothing has been said yet, however, about the reasons why they have changed or, in other words, about the dynamics that have caused the documented evolution. I will now handle this issue by looking no longer at the industrial shares but, instead, at the absolute flows. ${ }^{6}$ Starting from Hungary, traditional sectors have experienced a marked decline in both exports and imports: in particular, imports have diminished by $36 \%$ in the sectors of food and tobacco, and by $29 \%, 22 \%$, and $13 \%$, respectively, in the textile, leather, and wood industries. Similarly, transport equipments and the chemicals have seen their import flows decreasing by $22 \%$; however, the most dramatic reduction in real imports (50\%) has appeared for coke and petroleum. Imports have instead significantly risen for electric and optical equipments and for rubber and plastic products (28\% and $12 \%$, respectively). As to exports, they have declined by $44 \%$ in food and tobacco, by $28 \%$ in textiles, and by $34 \%$ in leather and leather products, with the strongest reductions, however, registered for coke and petroleum and for chemicals (35\% and 26\%) and for the nonmetallic mineral products (29\%). Along with imports, exports have sharply increased (52\%) for electric and 
Table 3. Industry shares of total manufacturing exports and imports (calculations based on OECD STAN Database for Industrial Analysis)

\begin{tabular}{|c|c|c|c|c|c|c|c|c|c|}
\hline \multirow[t]{2}{*}{ Sector } & \multicolumn{3}{|c|}{ Hungary } & \multicolumn{3}{|c|}{ Poland } & \multicolumn{3}{|c|}{ Czech Republic } \\
\hline & 1993 & 1997 & 2001 & 1993 & 1997 & 2001 & 1993 & 1997 & 2001 \\
\hline \multicolumn{10}{|l|}{ Exports } \\
\hline $\begin{array}{l}\text { Food products, beverages, } \\
\text { tobacco }\end{array}$ & 18 & 12 & 6 & 10 & 12 & 8 & 7 & 5 & 3 \\
\hline Textiles, textile products & 12 & 8 & 6 & 16 & 12 & 8 & 8 & 7 & 6 \\
\hline Leather, leather products & 4 & 2 & 2 & 2 & 2 & 2 & 2 & 1 & 1 \\
\hline Wood, wood products & 1 & 1 & 1 & 4 & 4 & 3 & 3 & 2 & 2 \\
\hline $\begin{array}{l}\text { Pulp, paper, paper } \\
\text { products }\end{array}$ & 1 & 2 & 2 & 2 & 3 & 4 & 4 & 3 & 3 \\
\hline Coke, refined petroleum & 4 & 2 & 2 & 2 & 2 & 2 & 3 & 3 & 1 \\
\hline $\begin{array}{l}\text { Chemicals, chemical } \\
\text { products }\end{array}$ & 13 & 9 & 6 & 8 & 9 & 6 & 11 & 8 & 6 \\
\hline Rubber, plastic products & 2 & 3 & 3 & 2 & 3 & 4 & 3 & 4 & 5 \\
\hline $\begin{array}{l}\text { Other nonmetallic mineral } \\
\text { products }\end{array}$ & 3 & 2 & 1 & 3 & 4 & 3 & 7 & 5 & 5 \\
\hline $\begin{array}{l}\text { Basic metals, fabricated } \\
\text { metal products }\end{array}$ & 10 & 8 & 6 & 20 & 17 & 12 & 19 & 15 & 13 \\
\hline $\begin{array}{l}\text { Machinery, equipments } \\
\text { n.e.c. }\end{array}$ & 7 & 7 & 7 & 7 & 7 & 7 & 12 & 13 & 12 \\
\hline $\begin{array}{l}\text { Electrical, optical } \\
\text { equipments }\end{array}$ & 12 & 29 & 36 & 6 & 9 & 12 & 7 & 13 & 20 \\
\hline Transport equipments & 9 & 14 & 20 & 14 & 8 & 21 & 12 & 16 & 19 \\
\hline Manufacturing n.e.c. & 4 & 1 & 2 & 4 & 8 & 8 & 2 & 5 & 4 \\
\hline \multicolumn{10}{|l|}{ Imports } \\
\hline $\begin{array}{l}\text { Food products, beverages, } \\
\text { tobacco }\end{array}$ & 5 & 4 & 4 & 8 & 6 & 5 & 6 & 5 & 4 \\
\hline Textiles, textile products & 9 & 7 & 5 & 11 & 8 & 7 & 4 & 5 & 5 \\
\hline Leather, leather products & 2 & 2 & 2 & 2 & 1 & 1 & 1 & 2 & 1 \\
\hline Wood, wood products & 1 & 1 & 1 & 1 & 1 & 1 & 1 & 1 & 2 \\
\hline $\begin{array}{l}\text { Pulp, paper, paper } \\
\text { products }\end{array}$ & 4 & 4 & 3 & 5 & 4 & 4 & 4 & 4 & 4 \\
\hline Coke, refined petroleum & 3 & 2 & 1 & 3 & 3 & 2 & 3 & 2 & 3 \\
\hline $\begin{array}{l}\text { Chemicals, chemical } \\
\text { products }\end{array}$ & 14 & 13 & 10 & 16 & 15 & 16 & 15 & 13 & 11 \\
\hline Rubber, plastic products & 4 & 4 & 4 & 4 & 5 & 5 & 4 & 5 & 6 \\
\hline $\begin{array}{l}\text { Other nonmetallic mineral } \\
\text { products }\end{array}$ & 2 & 2 & 2 & 2 & 3 & 2 & 2 & 2 & 2 \\
\hline $\begin{array}{l}\text { Basic metals, fabricated } \\
\text { metal products }\end{array}$ & 8 & 10 & 8 & 7 & 8 & 10 & 11 & 12 & 12 \\
\hline $\begin{array}{l}\text { Machinery, equipments } \\
\text { n.e.c. }\end{array}$ & 11 & 12 & 11 & 15 & 16 & 13 & 20 & 15 & 13 \\
\hline $\begin{array}{l}\text { Electrical, optical } \\
\text { equipments }\end{array}$ & 16 & 26 & 34 & 16 & 16 & 18 & 19 & 20 & 24 \\
\hline Transport equipments & 18 & 11 & 13 & 8 & 13 & 13 & 7 & 11 & 11 \\
\hline Manufacturing n.e.c. & 3 & 2 & 2 & 2 & 1 & 3 & 3 & 3 & 2 \\
\hline
\end{tabular}


optical equipment, suggesting a rising participation of the country in intraindustry trade relationships in this sector. Similar conclusions cannot be extended to transport equipments or to paper, printing, and publishing, for which the decrease in imports has been accompanied by a relevant increase in exports (36\% and $11 \%$, respectively).

The Polish experience is similar to the Hungarian one. Imports have, in fact, declined for traditional sectors such as food and tobacco (25\%) and textiles (21\%), as well as paper, printing, and publishing, coke and petroleum, chemicals ( $9 \%, 15 \%$, and $4 \%$, respectively), and machineries (10\%), while rising by $19 \%$ in transport equipments and - peculiarly - by $29 \%$ and $10 \%$ for wood and wood products and for the metallurgic sector. Also exports have declined for food and tobacco (17\%), textiles (32\%), chemicals (17\%), and machineries (3\%); strong reductions have been experienced also in leather (23\%), wood (17\%) and nonmetallic mineral products (16\%), as well as in the metallurgic sector (26\%); this may suggest a change in comparative advantage from these productions towards other branches such as paper, printing, and publishing (34\%), rubber and plastic products (36\%) and electric and optical equipments (25\%). Finally, increasing exports (17\%) and imports for the transport equipments indicate that Poland might have progressively developed intraindustry trade links in this sector.

In the Czech Republic, things are somewhat different, since imports have witnessed upsurges in all industries (23\% on average), and especially in textiles (34\%), in rubber and plastic products (40\%), in electric and optical equipments (33\%), and in transport equipments (43\%). In the last three sectors, moreover, import growth has occurred together with significant export growth; as in the other two countries, this evidence comes in favour of raising intraindustry trade integration. Not negligible export increases have been registered also for paper, printing, and publishing (27\%) and machineries (22\%), whereas the only industries in which exports have declined are food and tobacco (15\%), leather and leather products (28\%), and chemicals (3\%).

The analysis conducted up to now can be enriched by providing additional information regarding the degree of openness of each industry. For this purpose, I use the ratio of total trade flows (imports plus exports) to value added as a synthetic indicator (Fig. 5).

Independently of the previously illustrated patterns, all sectors have significantly opened up to international trade during the decade. ${ }^{7}$ The indicator has increased particularly for textiles (Hungary, 21\%; Poland, 20\%; Czech Republic, 32\%), leather and leather products (Hungary, 33\%; Poland, 39\%; Czech Republic,30\%), coke and petroleum (Hungary, 24\%; Poland, 72\%; Czech Republic, 81\%), rubber and plastic products (Hungary, 38\%; Poland, 27\%; Czech Republic, 16\%), machineries (Hungary, 39\%; Poland, 26\%; Czech Republic, 19\%), and electric and optical equipment (Hungary, 37\%; Poland, 28\%; Czech Republic, 16\%); higher trade openness has evidently been reached 

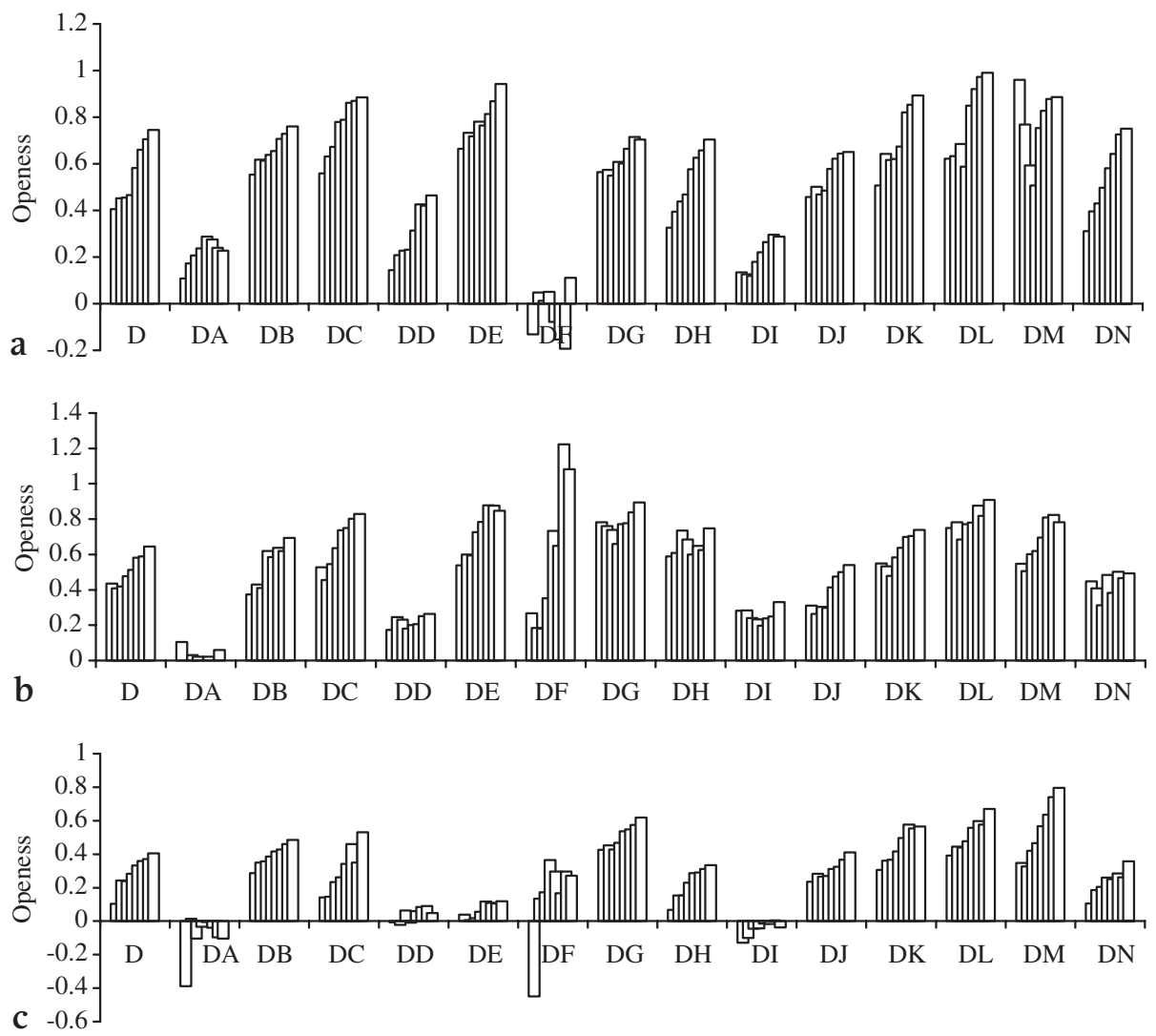

Fig. 5. Degree of openness (log[(exports + imports)/value added]): a Hungary, b Czech Republic, c Poland. Calculations based on OECD STAN Database for Industrial Analysis. For symbols of classification, see legend of Fig. 4

also for Czech and Polish transport equipment (23\% and 45\%, respectively) and for Hungarian and Czech paper, printing, and publishing (28\% and 31\%). The fact that export and import flows have generally diminished in traditional branches - textile and leather products above all - implies that the higher openness degree has resulted from an even slower growth in the value added generated by those industries; in the remaining sectors, in contrast, the contemporary increase in trade flows and trade openness reveals that higher fractions of total value added have been progressively accounted for by the rapid international integration.

\section{Foreign direct investment}

Together with larger and reoriented trade flows, FDI has represented another important expression of the rapid process of international integration that 
Poland, Hungary, and the Czech Republic have undertaken during the 1990 s. Among the three countries, Hungary has attracted the largest FDI inflows until 1996; then, Poland has become the leading country in FDI attraction, while the Czech Republic has gained the leadership only in 2002. In order to clarify the current role of the triad among the CEECs, it should be enough to note that after the sharp increase in inward stocks during the $1990 \mathrm{~s}^{8}{ }^{8}$ the three economies performed highly also in 2001, when more than $80 \%$ of total inflows in Central and Eastern Europe have been directed towards these countries (UNCTAD 2002b). ${ }^{9}$ In per-capita terms, 2001 inflows in the Czech Republic and in Hungary have been higher than in Poland (USD 408, 207, and 201, respectively); FDI in Poland has also lagged behind in percent of GDP (3.6\% against $4 \%$ and $8.5 \%$ in Hungary and the Czech Republic, respectively).

Even though the tertiary sector has progressively acquired importance in recent years and accounts nowadays for more than $70 \%$ of total inflows in each country, I will now focus only on the secondary sector, describing the patterns of foreign presence in the six branches for which a sufficiently long time series for FDI stocks is available. ${ }^{10}$ During the 1990s, manufacturing stocks rose significantly in the three countries, increasing from 10,632 million to 322,153 million Koruna in the Czech Republic between 1993 and 2001 and from 319,265 to 1,080,800 million Forint in Hungary between 1992 and 2000; in Poland, they reached 57,410 million Zloty in 2000, starting from 4,108 million in 1994. At the same time, the industrial composition has changed as well. In general, while at the beginning of the decade the largest fractions of total manufacturing stocks were concentrated in the food industry and, to a lower extent, in the textiles and in chemicals sectors, the bulk of foreign investments is nowadays distributed among the high-tech, mechanical, and metallurgic industries; moreover, a not negligible share of total stocks is still accounted for by the chemical sector. A synthetic representation of the industrial composition from the early 1990s toward the present time is provided in Tables $4-6$.

First thing to notice is the marked fall in the food industry share of total stocks, which has primarily concerned the Czech Republic without sparing, however, the other two countries. Tables $4-6$ also suggest that today foreign presence is highly concentrated in a few industries: in particular, the chemical, machinery and metallurgic sectors account for almost $2 / 3$ of total manufacturing stocks in the Czech Republic (Table 4); similarly, the chemical, metallurgic, and transport equipment sectors have a cumulative share of about $50 \%$ in Hungary (Table 5) ${ }^{11}$ and even higher in Poland (Table 6). Things do not change at all when FDI are weighted by the value added generated by the corresponding industry: the ratio reaches the highest values for the machineries (85\%), chemical (73\%), and metallurgic sectors (87\%) in the Czech Republic; in the chemical (66\%) and metallurgic sectors (37\%) in Hungary; in the transport equipments (26\%) and chemical sectors (10\%) in Poland. 
Table 4. Industry shares of total FDI stock in the Czech Republic (calculations based on Czech National Bank, Balance of Payments Statistics, 2004 online)

\begin{tabular}{|c|c|c|c|c|c|c|c|c|c|}
\hline Sector & 1993 & 1994 & 1995 & 1996 & 1997 & 1998 & 1999 & 2000 & 2001 \\
\hline Food, tobacco & 63 & 36 & 26 & 22 & 22 & 18 & 18 & 15 & 14 \\
\hline $\begin{array}{l}\text { Textiles, wearing apparel, } \\
\text { leather }\end{array}$ & 0 & 0 & 0 & 1 & 2 & 4 & 3 & 3 & 4 \\
\hline Wood, paper, publishing & 0 & 0 & 0 & 4 & 7 & 7 & 8 & 7 & 7 \\
\hline $\begin{array}{l}\text { Refined petroleum, } \\
\text { chemicals }\end{array}$ & 5 & 8 & 9 & 21 & 19 & 14 & 16 & 16 & 15 \\
\hline Nonmetallic products & 14 & 13 & 16 & 14 & 13 & 13 & 15 & 11 & 10 \\
\hline $\begin{array}{l}\text { Basic metals, metal } \\
\text { products }\end{array}$ & 0 & 0 & 0 & 0 & 3 & 11 & 10 & 11 & 10 \\
\hline Machinery, equipment & 18 & 43 & 49 & 38 & 32 & 30 & 27 & 34 & 37 \\
\hline $\begin{array}{l}\text { Recycling, other } \\
\text { manufacturing }\end{array}$ & 0 & 0 & 0 & 0 & 2 & 3 & 3 & 3 & 3 \\
\hline Total & 100 & 100 & 100 & 100 & 100 & 100 & 100 & 100 & 100 \\
\hline
\end{tabular}

Table 5. Industry shares of total FDI stock in Hungary (calculations based on OECD, International Direct Investments Statistics)

\begin{tabular}{|c|c|c|c|c|c|c|c|c|c|}
\hline Sector & 1992 & 1993 & 1994 & 1995 & 1996 & 1997 & 1998 & 1999 & 2000 \\
\hline Food products & 37 & 34 & 33 & 28 & 27 & 31 & 31 & 29 & 31 \\
\hline $\begin{array}{l}\text { Total textile, wood } \\
\text { activities }\end{array}$ & 12 & 11 & 11 & 12 & 13 & 13 & 12 & 12 & 12 \\
\hline $\begin{array}{l}\text { Total petroleum, } \\
\text { chemical, rubber, } \\
\text { plastic products }\end{array}$ & 24 & 19 & 22 & 27 & 25 & 25 & 23 & 24 & 23 \\
\hline $\begin{array}{l}\text { Total metal, } \\
\text { mechanical products }\end{array}$ & 11 & 11 & 10 & 11 & 13 & 16 & 15 & 15 & 15 \\
\hline $\begin{array}{l}\text { Total machinery, } \\
\text { computers, RTV, } \\
\text { communications }\end{array}$ & 6 & 15 & 15 & 14 & 15 & 4 & 5 & 6 & 7 \\
\hline $\begin{array}{l}\text { Total vehicles, } \\
\text { other transport } \\
\text { equipments }\end{array}$ & 10 & 10 & 9 & 8 & 7 & 11 & 14 & 14 & 12 \\
\hline Total & 100 & 100 & 100 & 100 & 100 & 100 & 100 & 100 & 100 \\
\hline
\end{tabular}

It should be clear by this time, that significant changes have occurred in the industry-level composition of FDI during the reference period; this evidence, in turn, stimulates a more careful analysis of the trends in foreign investments for last decade, in order to appreciate their pace and disentangle their country-specific features. When doing so, first of all, a clear regularity emerges: FDI growth rates for the food and tobacco have been lower than average everywhere but in Poland, where the stocks have grown slightly faster than average. Apart from this common trend, which has been of course one of the determinants of the previously documented overall changes in the 
Table 6. Industry shares of total FDI stock in Poland (calculations based on OECD, International Direct Investments Statistics)

\begin{tabular}{|c|c|c|c|c|c|c|c|}
\hline Sector & 1994 & 1995 & 1996 & 1997 & 1998 & 1999 & 2000 \\
\hline Food products & 35 & 32 & 30 & 30 & 34 & 27 & 27 \\
\hline $\begin{array}{l}\text { Total textile, wood } \\
\text { activities }\end{array}$ & 24 & 25 & 16 & 16 & 13 & 16 & 16 \\
\hline $\begin{array}{l}\text { Total petroleum, } \\
\text { chemical, rubber, } \\
\text { plastic products }\end{array}$ & 19 & 24 & 21 & 21 & 18 & 20 & 21 \\
\hline $\begin{array}{l}\text { Total metal, } \\
\text { mechanical products }\end{array}$ & 13 & 11 & 10 & 11 & 10 & 13 & 11 \\
\hline $\begin{array}{l}\text { Total machinery, } \\
\text { computers, RTV, } \\
\text { communications }\end{array}$ & 1 & 3 & 3 & 3 & 3 & 3 & 4 \\
\hline $\begin{array}{l}\text { Total vehicles, } \\
\text { other transport } \\
\text { equipments }\end{array}$ & 8 & 5 & 20 & 19 & 22 & 21 & 21 \\
\hline Total & 100 & 100 & 100 & 100 & 100 & 100 & 100 \\
\hline
\end{tabular}

industrial composition of FDI stocks, the patterns of foreign presence have actually differed significantly in the three economies. Starting from the Czech Republic (Fig. 6a), foreign penetration into textiles and leather has sped up in 1995 and kept on rising afterwards, so that today's stocks by far exceed 1993 levels. The first part of the decade has also experienced a rapid increase for the petroleum and chemical industries and for machineries, which have however diminished their attractiveness in the second half of the 1990s, when the wood and paper and publishing together with the metallurgic sector have received the largest investments; in recent years, moreover, they kept on attracting significant investments, and as a result, they account today for almost $80 \%$ of total manufacturing inflows together with chemicals and machineries.

In Hungary, FDI stocks in textile, leather, wood, and paper products have moved much more closely to the overall trend in manufacturing (Fig. 6b). After the upsurge in 1995, moreover, the petroleum, chemical, and rubber industry has experienced a slightly slower than average growth during the last years of the decade, whereas transport equipment and the metallurgic sector have registered relevant increases in foreign presence since 1996, similarly to their Czech counterparts. Machinery, RTV, computers, and communication industry, finally, is an interesting outlier: after a sharp increase in foreign presence during the first half of the 1990s - which was probably the consequence of the market-oriented reforms and the relevant restructuring process put in place in this country even before the collapse of the communist regime -, FDI stocks dramatically fell in 1996, suffering much more than in other industries from the stagnation experienced by the Hungarian economy in the same year. Since then, however, foreign presence 

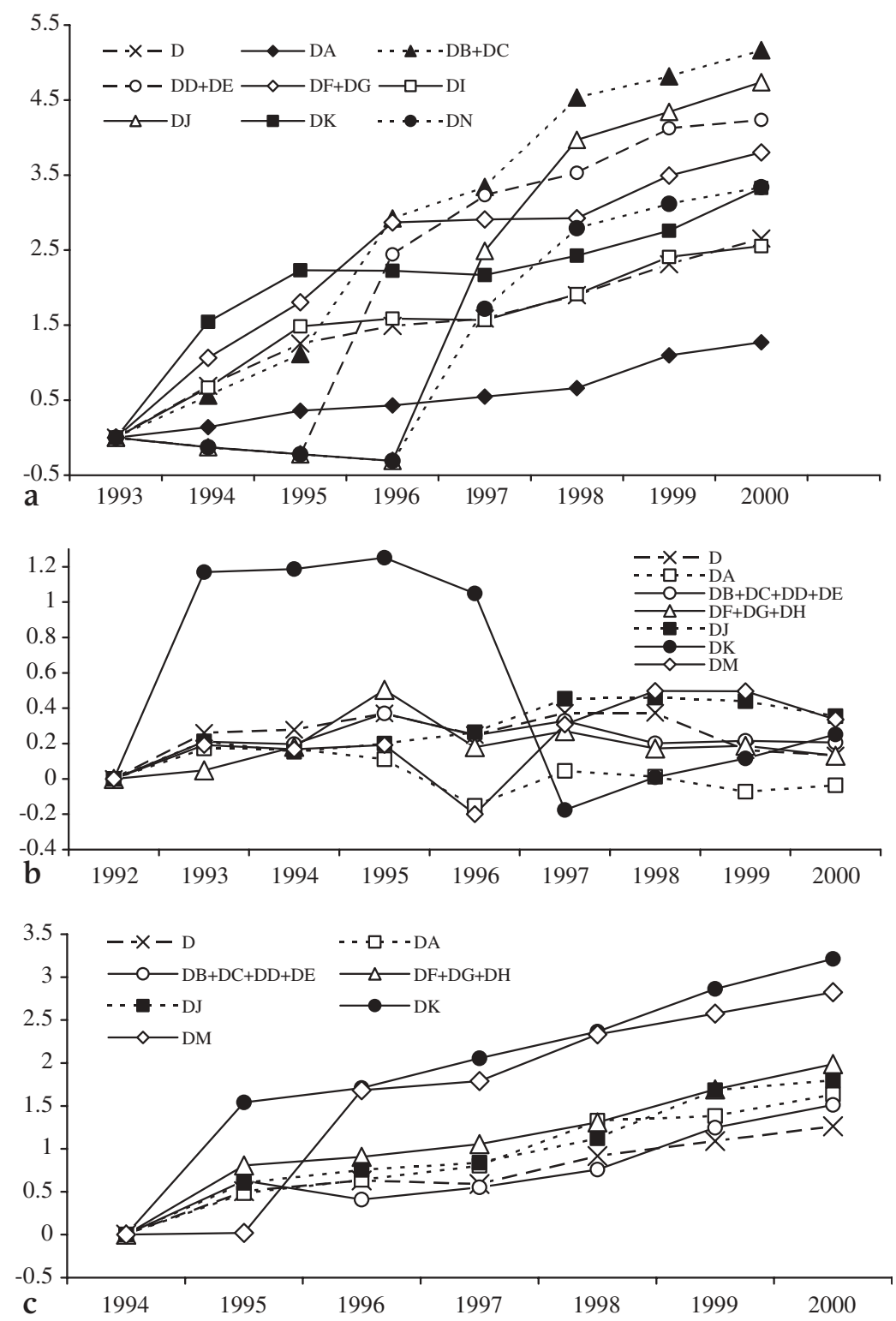

Fig. 6. FDI stocks in manufacturing by industry (log level minus log first-year level): a Czech Republic (calculations based on Czech National Bank, Balance of Payments Statistics), b Hungary (calculations based on OECD, International Direct Investment Statistics), $\mathbf{c}$ Poland (same source as for Hungary). For symbols of classification, see legend of Fig. 4

in the high-tech industry has started rising again at a $14 \%$ average annual rate, so that the sector has already recovered almost half of its 1996 share of total FDI stocks. 
In Poland, finally, FDI has increased significantly for machineries, transport equipments, and petroleum, chemicals, and rubber; as in Hungary, growth has been less rapid for the textile, leather, wood, and paper products (Fig. 6c).

\section{Correlation analysis}

Up to now, I have analyzed the labour market issues and the two forms of international integration separately. However, it should be noted on the one hand that wage inequality and changes in the skill composition of the labour force may be linked to both increasing trade integration and rising foreign direct penetration. Theoretically speaking, in fact, the Stolper-Samuelson theorem attributes important redistributive effects to international trade; more recently, furthermore, the apparent inadequacy of a "trade-based explanation" to justify the stylized facts on the expansion in the wage gap in many developed and developing countries (Lawrence and Slauther 1993, Bhagwati and Dehejia 1994) has stimulated a new stream of literature on the possible skill-biased influence of FDI (Feenstra and Hanson 1997). On the other hand, export and import patterns may not be completely independent of the investment decisions by multinational corporations. Namely, foreign firms activities may either contribute to or substitute for the recipient country's exports and imports, depending on the vertical or horizontal nature of the firms themselves.

For these reasons, additional important insights may be provided by a joint analysis of the three phenomena. Unfortunately, the lack of sufficiently disaggregated data for the three countries has so far prevented reaching clear conclusions on these topics. Nonetheless, available data are enough to test at least the existence of a relation between the three issues as argued in theory and, if any, to determine its sign. Maintaining the industry-level perspective and the more parsimonious classification used in the previous section, I have computed for this purpose a set of correlation coefficients between two different skill inequality indicators - skilled labour shares of total wage bill (WSH) and employment (ESH) -, export and import flows, and FDI stocks. I will report both current-year coefficients and results from correlation analysis between lagged (up to three times) and current values of each indicator. ${ }^{12}$

Let us start from the wage inequality-international integration relation and consider FDI first (Table 7). The most clear-cut evidence emerges for Poland: in all six manufacturing industries, correlation coefficients are particularly high and positive, when either ESH or WSH are examined. This suggests that increasing (decreasing) FDI stocks are associated with higher (lower) shares of skilled labour in total wage bill and employment. The only relevant exception is the transport equipments sector, where ESH is negatively correlated with FDI. Results are robust to the use of lagged stocks, as coefficients remain positively signed and vary insignificantly in magnitude. 
Table 7. Correlations coefficients between FDI stocks and the skilled-labour shares of total wage bill and employment (calculation based on the countries' statistical yearbooks and OECD, International Direct Investment Statistics)

\begin{tabular}{|c|c|c|c|c|c|c|c|c|}
\hline \multirow[t]{2}{*}{ Country and sector } & \multicolumn{4}{|l|}{ WSH } & \multicolumn{4}{|l|}{ ESH } \\
\hline & Current & 1 lag & 2 lags & 3 lags & Current & 1 lag & 2 lags & 3 lags \\
\hline \multicolumn{9}{|l|}{ Poland } \\
\hline Food products & 0.88 & 0.98 & 0.90 & 0.92 & 0.85 & 0.99 & 0.88 & 0.90 \\
\hline $\begin{array}{l}\text { Total textile, wood } \\
\text { activities }\end{array}$ & 0.98 & 0.90 & 0.51 & 0.56 & 0.91 & 0.76 & 0.27 & 0.61 \\
\hline $\begin{array}{l}\text { Total petroleum, } \\
\text { chemical, rubber, } \\
\text { plastic products }\end{array}$ & 0.99 & 0.97 & 0.97 & 0.92 & 0.99 & 0.98 & 0.98 & 0.89 \\
\hline $\begin{array}{l}\text { Total metal, } \\
\text { mechanical products }\end{array}$ & 0.98 & 0.83 & 0.88 & 0.95 & 0.97 & 0.74 & 0.80 & 0.95 \\
\hline $\begin{array}{l}\text { Total machinery, } \\
\text { computers, RTV, } \\
\text { communications }\end{array}$ & 0.97 & 0.93 & 0.96 & 0.94 & 0.68 & 0.57 & 0.65 & 0.76 \\
\hline $\begin{array}{l}\text { Total vehicles, } \\
\text { other transport } \\
\text { equipments }\end{array}$ & 0.78 & 0.76 & 0.66 & 0.85 & -0.44 & -0.50 & -0.53 & -0.31 \\
\hline \multicolumn{9}{|l|}{ Hungary } \\
\hline Food products & -0.18 & -0.56 & -0.65 & -0.37 & 0.07 & -0.34 & -0.60 & -0.22 \\
\hline $\begin{array}{l}\text { Total textile, wood } \\
\text { activities }\end{array}$ & 0.36 & -0.52 & -0.49 & -0.48 & 0.19 & -0.52 & -0.47 & -0.37 \\
\hline $\begin{array}{l}\text { Total petroleum, } \\
\text { chemical, rubber, } \\
\text { plastic products }\end{array}$ & -0.73 & -0.44 & 0.35 & 0.62 & -0.75 & 0.35 & 0.57 & 0.60 \\
\hline $\begin{array}{l}\text { Total metal, } \\
\text { mechanical products }\end{array}$ & -0.01 & 0.58 & 0.47 & 0.29 & -0.47 & -0.74 & -0.51 & -0.83 \\
\hline $\begin{array}{l}\text { Total machinery, } \\
\text { computers, RTV, } \\
\text { communications }\end{array}$ & 0.81 & 0.75 & 0.34 & -0.67 & 0.86 & 0.94 & 0.53 & -0.25 \\
\hline $\begin{array}{l}\text { Total vehicles, } \\
\text { other transport } \\
\text { equipments }\end{array}$ & -0.74 & -0.59 & -0.25 & -0.21 & -0.67 & -0.60 & -0.36 & -0.27 \\
\hline \multicolumn{9}{|l|}{ Czech Republic } \\
\hline Food and tobacco & 0.78 & 0.88 & 0.76 & 0.88 & -0.3 & -0.71 & -0.77 & -0.77 \\
\hline $\begin{array}{l}\text { Textiles, wearing apparel, } \\
\text { leather }\end{array}$ & -0.55 & -0.61 & -0.46 & -0.28 & -0.83 & -0.76 & -0.64 & -0.49 \\
\hline Wood, paper, publishing & 0.25 & -0.25 & -0.56 & -0.6 & -0.71 & -0.89 & -0.86 & -0.79 \\
\hline $\begin{array}{l}\text { Refined petroleum, } \\
\text { chemicals }\end{array}$ & 0.9 & 0.88 & 0.87 & 0.82 & 0.84 & 0.85 & 0.81 & 0.74 \\
\hline Nonmetallic products & 0.38 & 0.06 & -0.08 & -0.05 & -0.4 & -0.6 & -0.53 & -0.31 \\
\hline $\begin{array}{l}\text { Basic metals, metal } \\
\text { products }\end{array}$ & -0.4 & -0.68 & -0.08 & -0.73 & -0.95 & -0.97 & -0.92 & -0.76 \\
\hline Machinery, equipment & 0.39 & 0.28 & 0.25 & 0.001 & -0.84 & -0.78 & -0.73 & -0.8 \\
\hline $\begin{array}{l}\text { Recycling, other } \\
\text { manufacturing }\end{array}$ & -0.31 & -0.09 & 0.14 & 0.31 & -0.62 & -0.37 & -0.16 & -0.04 \\
\hline
\end{tabular}


For the other two countries, the picture is much more confused, since coefficients differ both across industries and when different lags are used. For Hungary, the only significant evidence of high and positive correlation between FDI and WSH (ESH) is found in the machinery sector. In the other industries, coefficients are often negative, or very close to zero when positively signed. ${ }^{13}$ Moreover, while the use of lagged FDI does not generally switch the coefficients' sign in those sectors for which they had already turned out to be negative from current-period correlation analysis, it instead reverts the sign in such industries as textile and wood, where current coefficients have shown up being positive. For the Czech Republic, results are again mixed, although less than for Hungary. As to WSH, in such industries as food and tobacco, chemicals, and machineries, correlation is positive and quite high and, few exceptions aside, resists to the adoption of lagged FDI stocks. For ESH, coefficients are generally negative, both in current and lagged terms. This supports the idea that the positive relation between foreign presence and wage inequality does not pass through shifts in the relative demand schedule but acts in parallel with the ongoing transition process modifying the wage determination towards rules which are less rigid and more consistent with the actual skill distribution (Bruno et al. 2004).

Turning to exports and imports, results are much clearer: in general, both trade flows are negatively correlated with either WSH or ESH (Tables 8 and 9).

This result is consistent with the traditional explanations of the redistributive effects of international trade: unskilled labour tends to be favoured in relatively unskilled-labour abundant economies as Poland, Hungary, and the Czech Republic can be considered with respect to their major trading partner, the EU-15. The most important violations of such regularity can be summarized as follows.

In Hungary, WSH is positively and highly correlated with both exports and imports for chemicals, and just with imports for food and tobacco; a positive (but lesser) correlation shows up also for the metallurgic sector; ESH is positively and highly correlated for food and tobacco and, to a lesser extent, in the textile, wood and paper industry.

In the Czech Republic, a positive relation between WSH and both trade flows emerges for machineries and for chemicals; WSH is also slightly positively correlated with imports for food and tobacco and for the nonmetallic mineral products; coefficients for ESH are positive for chemicals when both imports and exports are considered.

In Poland, WSH is positively correlated with both trade flows for the chemical and metallurgic sectors, and just with imports for food and tobacco (similarly to ESH).

The evidence reported in previous sections should have pointed out quite eloquently that the three economies have remarkably opened up to international integration since the beginning of the transition process in 1989. This has 
Table 8. Correlation coefficients between current and lagged trade flows and the skilled-labour shares of total wage bill (calculations based on the countries' statistical yearbooks and OECD STAN Database for Industrial Analysis)

\begin{tabular}{|c|c|c|c|c|c|c|c|c|}
\hline \multirow[t]{2}{*}{ Country and sector } & \multicolumn{4}{|l|}{ Exports } & \multicolumn{4}{|l|}{ Imports } \\
\hline & Current & 1 lag & 2 lags & 3 lags & Current & 1 lag & 2 lags & 3 lags \\
\hline \multicolumn{9}{|l|}{ Poland } \\
\hline Food products & -0.63 & -0.4 & 0.12 & 0.38 & 0.8 & 0.4 & 0.38 & 0.79 \\
\hline $\begin{array}{l}\text { Total textile, wood } \\
\text { activities }\end{array}$ & -0.1 & 0.17 & 0.09 & 0.45 & 0.1 & 0.29 & 0.22 & 0.19 \\
\hline $\begin{array}{l}\text { Total petroleum, } \\
\text { chemical, rubber, } \\
\text { plastic products }\end{array}$ & 0.59 & 0.50 & 0.87 & 0.48 & 0.86 & 0.62 & 0.68 & 0.65 \\
\hline $\begin{array}{l}\text { Total metal, } \\
\text { mechanical products }\end{array}$ & 0.22 & 0.1 & -0.09 & 0.19 & 0.17 & 0.09 & -0.06 & -0.14 \\
\hline $\begin{array}{l}\text { Total machinery, } \\
\text { computers, RTV, } \\
\text { communications }\end{array}$ & -0.1 & -0.19 & -0.11 & -0.17 & -0.35 & -0.07 & 0.15 & 0.35 \\
\hline $\begin{array}{l}\text { Total vehicles, } \\
\text { other transport } \\
\text { equipments } \\
\text { Hungary }\end{array}$ & -0.93 & -0.89 & -0.71 & -0.59 & -0.94 & -0.81 & -0.43 & -0.37 \\
\hline Food products & -0.59 & -0.20 & 0.39 & 0.68 & 0.78 & 0.37 & 0.35 & 0.67 \\
\hline $\begin{array}{l}\text { Total textile, wood } \\
\text { activities }\end{array}$ & -0.09 & 0.13 & 0.12 & 0.57 & 0.01 & 0.17 & 0.18 & 0.16 \\
\hline $\begin{array}{l}\text { Total petroleum, } \\
\text { chemical, rubber, } \\
\text { plastic products }\end{array}$ & 0.63 & 0.51 & 0.9 & 0.55 & 0.83 & 0.6 & 0.62 & 0.6 \\
\hline $\begin{array}{l}\text { Total metal, } \\
\text { mechanical products }\end{array}$ & 0.16 & 0.05 & -0.05 & 0.17 & 0.14 & 0.07 & -0.03 & -0.1 \\
\hline $\begin{array}{l}\text { Total machinery, } \\
\text { computers, RTV, } \\
\text { communications }\end{array}$ & -0.08 & -0.12 & -0.11 & -0.13 & -0.33 & -0.01 & 0.18 & 0.3 \\
\hline $\begin{array}{l}\text { Total vehicles, } \\
\text { other transport } \\
\text { equipments }\end{array}$ & -0.97 & -0.84 & -0.67 & -0.52 & -0.97 & -0.43 & -0.46 & -0.35 \\
\hline \multicolumn{9}{|l|}{ Czech Republic } \\
\hline Food and tobacco & -0.48 & -0.64 & -0.13 & 0.15 & 0.94 & 0.69 & 0.45 & 0.63 \\
\hline $\begin{array}{l}\text { Textiles, wearing apparel, } \\
\text { leather }\end{array}$ & -0.5 & -0.84 & -0.78 & -0.21 & -0.37 & -0.85 & -0.91 & -0.5 \\
\hline Wood, paper, publishing & 0.52 & 0.08 & -0.54 & -0.83 & 0.49 & -0.01 & -0.6 & -0.75 \\
\hline $\begin{array}{l}\text { Refined petroleum, } \\
\text { chemicals }\end{array}$ & 0.67 & 0.67 & 0.52 & 0.8 & 0.91 & 0.89 & 0.96 & 0.8 \\
\hline Nonmetallic products & 0.17 & -0.13 & 0.07 & -0.79 & 0.57 & 0.38 & 0.23 & -0.16 \\
\hline $\begin{array}{l}\text { Basic metals, metal } \\
\text { products }\end{array}$ & -0.22 & -0.49 & -0.68 & -0.76 & -0.01 & -0.28 & -0.55 & -0.82 \\
\hline Machinery, equipment & 0.53 & 0.55 & 0.35 & 0.1 & 0.43 & 0.41 & 0.34 & 0.38 \\
\hline $\begin{array}{l}\text { Recycling, other } \\
\text { manufacturing }\end{array}$ & -0.42 & -0.32 & -0.2 & 0.4 & -0.32 & -0.57 & -0.45 & -0.15 \\
\hline
\end{tabular}


Table 9. Correlation coefficients between current and lagged trade flows and the skilled-labour shares of employment (calculations based on the countries' statistical yearbooks and OECD STAN Database for Industrial Analysis)

\begin{tabular}{|c|c|c|c|c|c|c|c|c|}
\hline \multirow[t]{2}{*}{ Country and sector } & \multicolumn{4}{|l|}{ Exports } & \multicolumn{4}{|l|}{ Imports } \\
\hline & Current & 1 lag & 2 lags & 3 lags & Current & 1 lag & 2 lags & 3 lags \\
\hline \multicolumn{9}{|l|}{ Poland } \\
\hline Food products & -0.54 & -0.29 & 0.22 & 0.69 & 0.72 & 0.3 & 0.28 & 0.55 \\
\hline $\begin{array}{l}\text { Total textile, wood } \\
\text { activities }\end{array}$ & 0.15 & 0.4 & 0.38 & 0.58 & 0.27 & 0.43 & 0.41 & 0.36 \\
\hline $\begin{array}{l}\text { Total petroleum, } \\
\text { chemical, rubber, } \\
\text { plastic products }\end{array}$ & -0.56 & -0.68 & -0.27 & -0.62 & -0.36 & -0.62 & -0.58 & -0.61 \\
\hline $\begin{array}{l}\text { Total metal, } \\
\text { mechanical products }\end{array}$ & -0.8 & -0.81 & -0.79 & -0.73 & -0.86 & -0.83 & -0.85 & 0.91 \\
\hline $\begin{array}{l}\text { Total machinery, } \\
\text { computers, RTV, } \\
\text { communications }\end{array}$ & -0.74 & -0.66 & -0.65 & -0.57 & -0.82 & -0.57 & -0.46 & -0.35 \\
\hline $\begin{array}{l}\text { Total vehicles, } \\
\text { other transport } \\
\text { equipments }\end{array}$ & -0.92 & -0.87 & -0.73 & -0.65 & -0.9 & -0.82 & -0.55 & -0.52 \\
\hline \multicolumn{9}{|l|}{ Hungary } \\
\hline Food products & -0.5 & -0.39 & 0.17 & 0.72 & 0.78 & 0.31 & 0.25 & 0.58 \\
\hline $\begin{array}{l}\text { Total textile, wood } \\
\text { activities }\end{array}$ & 0.13 & 0.35 & 0.34 & 0.62 & 0.2 & 0.4 & 0.41 & 0.35 \\
\hline $\begin{array}{l}\text { Total petroleum, } \\
\text { chemical, rubber, } \\
\text { plastic products }\end{array}$ & -0.55 & -0.66 & -0.26 & -0.64 & -0.33 & -0.66 & -0.57 & -0.65 \\
\hline $\begin{array}{l}\text { Total metal, } \\
\text { mechanical products }\end{array}$ & -0.85 & -0.84 & -0.78 & -0.78 & -0.84 & -0.86 & -0.82 & -0.94 \\
\hline $\begin{array}{l}\text { Total machinery, } \\
\text { computers, RTV, } \\
\text { communications }\end{array}$ & -0.7 & -0.68 & -0.68 & -0.55 & -0.84 & -0.6 & -0.41 & -0.38 \\
\hline $\begin{array}{l}\text { Total vehicles, } \\
\text { other transport } \\
\text { equipments }\end{array}$ & -0.98 & -0.9 & -0.78 & -0.66 & -0.96 & -0.89 & -0.59 & -0.5 \\
\hline \multicolumn{9}{|l|}{ Czech Republic } \\
\hline Food and tobacco & -0.56 & 0.05 & 0.58 & 0.52 & 0.26 & -0.68 & -0.82 & -0.91 \\
\hline $\begin{array}{l}\text { Textiles, wearing apparel, } \\
\text { leather }\end{array}$ & -0.82 & -0.9 & -0.85 & -0.42 & -0.76 & -0.93 & -0.96 & -0.68 \\
\hline Wood, paper, publishing & -0.46 & -0.69 & -0.89 & -0.95 & -0.5 & -0.78 & -0.95 & -0.92 \\
\hline $\begin{array}{l}\text { Refined petroleum, } \\
\text { chemicals }\end{array}$ & 0.53 & 0.62 & 0.54 & 0.82 & 0.85 & 0.84 & 0.93 & 0.7 \\
\hline Nonmetallic products & -0.53 & 0.64 & -0.28 & -0.87 & -0.18 & -0.3 & -0.31 & -0.54 \\
\hline $\begin{array}{l}\text { Basic metals, metal } \\
\text { products }\end{array}$ & -0.85 & -0.85 & -0.85 & -0.83 & -0.8 & -0.81 & -0.86 & -0.94 \\
\hline Machinery, equipment & -0.84 & -0.73 & -0.72 & -0.67 & -0.76 & -0.62 & -0.59 & -0.5 \\
\hline $\begin{array}{l}\text { Recycling, other } \\
\text { manufacturing }\end{array}$ & -0.75 & -0.58 & -0.39 & 0.08 & -0.66 & -0.8 & -0.64 & -0.05 \\
\hline
\end{tabular}


Table 10. Correlations coefficients between current and lagged FDI stock and trade flows (calculations based on OECD STAN Database for Industrial Analysis and International Direct Inverstments Statistics)

\begin{tabular}{|c|c|c|c|c|c|c|c|c|}
\hline \multirow[t]{2}{*}{ Country and sector } & \multicolumn{4}{|l|}{ Exports } & \multicolumn{4}{|l|}{ Imports } \\
\hline & Current & $1 \mathrm{lag}$ & 2 lags & 3 lags & Current & 1 lag & 2 lags & 3 lags \\
\hline \multicolumn{9}{|l|}{ Poland } \\
\hline Food products & -0.6 & -0.67 & -0.22 & -0.68 & -0.55 & -0.8 & -0.31 & -0.68 \\
\hline $\begin{array}{l}\text { Total textile, wood } \\
\text { activities }\end{array}$ & 0.96 & 0.99 & 0.69 & 0.52 & 0.98 & 0.97 & 0.55 & 0.62 \\
\hline $\begin{array}{l}\text { Total petroleum, } \\
\text { chemical, rubber, } \\
\text { plastic products }\end{array}$ & 0.78 & 0.88 & 0.86 & 0.48 & 0.97 & 0.99 & 0.99 & 0.76 \\
\hline $\begin{array}{l}\text { Total metal, } \\
\text { mechanical products }\end{array}$ & 0.47 & 0.84 & 0.75 & 0.26 & 0.9 & 0.92 & 0.97 & 0.93 \\
\hline $\begin{array}{l}\text { Total machinery, } \\
\text { computers, RTV, } \\
\text { communications }\end{array}$ & 0.96 & 0.99 & 0.97 & 0.9 & 0.03 & 0.11 & 0.02 & 0.41 \\
\hline $\begin{array}{l}\text { Total vehicles, } \\
\text { other transport } \\
\text { equipments }\end{array}$ & 0.96 & 0.92 & 0.98 & 0.82 & 0.96 & 0.95 & 0.95 & 0.88 \\
\hline \multicolumn{9}{|l|}{ Hungary } \\
\hline Food products & 0.13 & -0.14 & 0.21 & 0.93 & 0.18 & -0.68 & -0.82 & 0.19 \\
\hline $\begin{array}{l}\text { Total textile, wood } \\
\text { activities }\end{array}$ & -0.84 & -0.19 & 0.12 & 0.82 & -0.77 & -0.28 & 0.06 & 0.78 \\
\hline $\begin{array}{l}\text { Total petroleum, } \\
\text { chemical, rubber, } \\
\text { plastic products }\end{array}$ & -0.57 & -0.39 & 0.03 & 0.51 & -0.67 & -0.43 & 0.03 & 0.57 \\
\hline $\begin{array}{l}\text { Total metal, } \\
\text { mechanical products }\end{array}$ & 0.53 & 0.87 & 0.83 & 0.81 & 0.55 & 0.88 & 0.85 & 0.85 \\
\hline $\begin{array}{l}\text { Total machinery, } \\
\text { computers, RTV, } \\
\text { communications }\end{array}$ & -0.71 & -0.85 & -0.82 & -0.23 & -0.75 & -0.95 & -0.85 & -0.12 \\
\hline $\begin{array}{l}\text { Total vehicles, } \\
\text { other transport } \\
\text { equipments }\end{array}$ & 0.78 & 0.71 & 0.38 & 0.05 & 0.77 & 0.73 & 0.37 & 0.04 \\
\hline \multicolumn{9}{|l|}{ Czech Republic } \\
\hline Food and tobacco & -0.14 & 0.43 & 0.5 & 0.24 & 0.72 & 0.8 & 0.7 & 0.49 \\
\hline $\begin{array}{l}\text { Textiles, wearing apparel, } \\
\text { leather }\end{array}$ & 0.85 & 0.76 & 0.72 & 0.79 & 0.78 & 0.67 & 0.62 & 0.78 \\
\hline Wood, paper, publishing & 0.92 & 0.95 & 0.95 & 0.96 & 0.93 & 0.92 & 0.87 & 0.92 \\
\hline $\begin{array}{l}\text { Refined petroleum, } \\
\text { chemicals }\end{array}$ & 0.84 & 0.83 & 0.59 & 0.51 & 0.99 & 0.96 & 0.84 & 0.85 \\
\hline Nonmetallic products & 0.92 & 0.97 & 0.87 & 0.79 & 0.91 & 0.95 & 0.94 & 0.83 \\
\hline $\begin{array}{l}\text { Basic metals, metal } \\
\text { products }\end{array}$ & 0.91 & 0.86 & 0.9 & 0.81 & 0.88 & 0.79 & 0.86 & 0.73 \\
\hline Machinery, equipment & 0.85 & 0.84 & 0.97 & 0.91 & 0.88 & 0.95 & 0.81 & 0.32 \\
\hline $\begin{array}{l}\text { Recycling, other } \\
\text { manufacturing }\end{array}$ & 0.94 & 0.84 & 0.75 & 0.71 & 0.79 & 0.66 & 0.57 & 0.57 \\
\hline
\end{tabular}


basically been obtained through a strong increase and a marked redirection of trade flows, on the one hand, and through a new inclination towards direct presence by foreign investors, on the other. Definitely more controversial, though, is the relationship that might have established between these two channels. Indeed, multinationals' activities in the host country may either contribute to or substitute for the same country's exports and imports; the firms nature is one of the determinants of the different influence of FDI on trade patterns: namely, vertical multinational enterprises are more likely to stimulate higher exports and imports through the relocation of production stages in the host country, whereas horizontal and market-seeking multinational enterprises might displace domestic exports and imports. In order to have a rough idea of which of the two motives might have determined the location decision of multinational firms in Poland, Hungary, and the Czech Republic, Table 10 reports correlation coefficients between current and lagged FDI stocks and both exports and imports at an industry level.

Generally speaking, a very strong and positive correlation is found in almost all branches; the only relevant exceptions are machineries, textiles, wood and paper, and chemicals in Hungary, along with food and tobacco in Poland. Although based on aggregate data, the negative sign reveals that in these sectors foreign affiliate activity displaces exports and imports and thus may suggest a prevalently horizontal and market-seeking nature of multinationals. In contrast, the positive correlation in the remaining industries may signal that transnational corporations delocalize stages of production perhaps to exploit cost and wage differentials relative to the home country; although, once again, no definite conclusion can be drawn, this positive and high FDI-trade correlation should be more consistent with a vertically integrated structure of multinationals than with the opposite.

\section{Conclusions}

After the fall of the communist regime, dramatic changes have occurred along both the political and the economic dimension in all CEECs. Fifteen years have passed since the formal beginning of the transition process and today the most outstanding CEECs can finally be considered as perfectly functioning market economies, able to participate in the finest political and economic expression of international integration in Europe: the EU.

Focusing on the three leading countries in the region between 1993 and 2001, this paper has analyzed the changes occurring across the manufacturing branches in two different but related aspects: the skill composition of the workforce and the earning structure by skills, on the labour market side; the direction and the industrial composition of trade flows together with the penetration by foreign investors, on the international integration side. Results can be summarized as follows. Starting from the labour market 
side, clear evidence of rising wage inequality has emerged in all countries, as the skill premium has increased everywhere during the reference period. Almost all sectors have been affected by significant skill premium upsurges in the three CEECs, although the relative wage of the skilled has grown much faster in the Czech and Polish industries than in the Hungarian ones. At the same time, relative skilled labour demand has augmented in Poland, behaving as in other developed and developing economies; the chemical, petroleum, and publishing industries have accounted for the bulk of the overall increase in relative skilled employment in manufacturing, together with food and tobacco. In contrast, relative skilled labour demand has shown a peculiar trend in Hungary and in the Czech Republic, where it has declined in the presence of increasing wage inequality; although the same industries as in Poland have experienced rises in the relative skilled labour demand also in those countries, the declines in the remaining branches have been sufficiently strong to drive down the relative skilled employment. As a result, if measured by the skilled labour share of total wage bill, the worsening in wage disparities appears much more widespread in Poland and, to a lesser extent, in the Czech Republic than in Hungary, where the overall rise has been mainly determined in two manufacturing industries: chemicals and food and tobacco.

Turning to the international integration side, after the fall of the socialist regime, trade flows have been significantly redirected towards the EU and, to a lesser extent, towards the United States and Asian countries. Traditional sectors have lost relevance in total flows in favour of high-tech and capital-intensive industries; nonetheless, the openness degree has increased in all sectors, suggesting that higher trade integration has been acquired by the three countries in the 1990s. During the same period, FDI has gained significant importance too. Apart from food and tobacco, all sectors have received increasing investments by multinational firms; as a result, machineries, chemicals, and transport equipments today account for the highest share in total manufacturing stocks, together with the metallurgic industry.

Finally, correlation analysis has revealed that the two phenomena analyzed in this paper are not independent of each other. In particular, trade flows and FDI are generally linked by a positive relation, which may point in favour of a vertically integrated structure of multinational firms; both exports and imports are negatively correlated with the skilled labour shares of total wage bill and employment, supporting the view of an unskilled-biased influence of international trade which may be explained on the grounds of the difference in labour endowments between these countries and their major trading partners; finally, no clear evidence has emerged about the relation between FDI and the two labour marker indicators, at least in the case of Hungary and the Czech Republic. 
Acknowledgment. I gratefully thank Anna M. Falzoni and Giovanni S. F. Bruno for useful comments and suggestions on earlier versions of this paper. I gratefully acknowledge financial support from PRIN 2002 "Tendenze nella specializzazione commerciale e produttiva in un'area regionale integrata: l'Italia nella UE allargata”. The usual disclaimers apply.

\section{Notes}

1 The industrial breakdown of FDI data is much more parsimonious; observations are available, in fact, for just six industries in the case of Poland and Hungary and for at most eight in the case of the Czech Republic, thanks to the slightly more disaggregated classification provided by the "Balance of Payments Statistics" of the Czech National Bank (www.cnb.cz).

2 Author's calculations based on each country's statistical yearbooks (various years).

3 Especially in electric and optical equipment and in transportation equipments, where the relative skilled-labour demand has decreased by $23 \%$ and $13 \%$.

4 The skilled-labour share of total employment (ESH) has moved accordingly, as expected; generally speaking, in all countries the largest increases have been documented in the four industries where the skill ratio has risen faster - paper, printing, and publishing, coke and petroleum, chemicals, and rubber and plastic; the share has instead declined, or stayed almost constant, elsewhere.

5 In order to save space, I do not report the table containing the classification of industries based on their factor intensity; the table is available from the author upon request.

6 Reported figures are at constant 1995 U.S. dollars.

7 The only two exceptions - although quantitatively less relevant - are the Hungarian transport equipments and the Czech food and tobacco, where the degree of trade openness has diminished by $7 \%$ and $5 \%$, respectively.

8 Between 1990 and 2000, the ratio of FDI stock to GDP has grown from values virtually close to zero (3.9\% in the Czech Republic, $0.2 \%$ in Poland, $1.7 \%$ in Hungary) to more than $40 \%$ in Hungary and in the Czech Republic and to more than 20\% in Poland (UNCTAD 2002b).

9 Together with Slovakia and the Russian Federation.

10 For the Czech Republic, I will rely upon the slightly more disaggregated classification provided by the "Balance of Payments Statistics" of the Czech National Bank (www.cnb.cz).

11 Different from the Czech counterpart, Hungary's food industry still accounts for almost one third of total stocks; this is probably due to the higher agricultural potential of this country.

12 Lagged values are used to keep track of the fact that a relation among the analyzed phenomena may take some time to show up.

13 In particular, the sectors of petroleum, chemicals, and rubber and of transport equipments are characterized by the strongest negative relation between FDI and both WSH and ESH.

\section{References}

Aghion P, Blanchard OJ (1994) On the speed of transition in Central Europe. In: Fisher S, Rotemberg JJ (eds) NBER macroeconomic annual 1994. MIT Press, Cambrige, Mass, pp $283-320$

Barrell R, Holland D (2000) Foreign direct investment and enterprise restructuring in Central Europe. Economics of Transition 8: 477-504

Bhagwati J, Dehejia V (1994) Freer trade and wages of the unskilled - is Marx striking again? In: Bhagwati J, Kosters MH (eds) Trade and wages. American Enterprise Institute Press, Washington, DC, pp 36-75

Bedi S, Cieslik A (2002) Wages and wage growth in Poland: the role of foreign direct investment. Economics of Transition 10: 1-27 
Berman E, Bound J, Griliches Z (1994) Changes in the demand for skilled labour within U.S. manufacturing industries: evidence from the annual survey of manufacturing. Quarterly Journal of Economics 109: 367-397

Blanchard OJ, Kremer M (1997) Disorganization. Quarterly Journal of Economics 112: 1091-1126

Blonigen BA, Slaughter MJ (2000) Foreign affiliate activity and U.S. skill upgrading. Review of Economics and Statistics 83: 362-376

Boeri T (2000) Structural change, welfare systems and labor reallocation: lessons from the transition of formerly planned economies. Oxford University Press, Oxford

Boeri T, Brücker H (2002) The impact of Eastern Enlargement on employment and labour markets in the EU member states. European Integration Consortium: DIW, CEPR, FIEF, IAS, IGIER, Berlin and Milano

Boeri T, Terrel K (2002) Institutional determinants of labour reallocation in transition. Journal of Economics Perspectives, 16: 51-76

Bruno GSF, Crinò R, Falzoni AM (2004) Foreign direct investment, wage inequality and skilled labor demand in EU accession countries. Working Paper 154, Centre of Research on Innovation and Internationalization, Bocconi University, Milan

Campos NF, Coricelli F (2002) Growth in transition: what we know, what we don't and what we should. Journal of Economic Literature 40: 793-836

Commander S, Kollo J (2004) The changing demand for skills: evidence from transition. Discussion Paper 1073, Forschungsinstitut zur Zukunft der Arbeit, Bonn

Commander S, Coricelli F, Staehe K (1992) Wages and employment in the transition to a market economy. Working Paper 93, World Bank, Washington, DC

De Benedictis L, Tajoli L (2003) Economic integration, similarity and convergence in the EU and CEECs trade structures. Working Paper 148, Centre of Research on Innovation and Internationalization, Bocconi University, Milan

Egger P, Stehrer R (2003) International outsourcing and the skill-specific wage bill in Eastern Europe. World Economy 26: 61-72

European Commission (2002) Employment in Europe. European Commission, Directorate General for Employment and Social Affair, European Communities, Bruxelles

Facchini G, Segnana ML (2003) Growth at the EU periphery: the next enlargement. Quarterly Review of Economics and Finance 43: 827-862

Feenstra RC, Hanson GH (1997) Foreign direct investment and relative wages: evidence from Mexico's maquiladoras. Journal of International Economics 42: 371-393

Hunya G (2000) Foreign direct investment in CEEC manufacturing. In: Landesmann M (ed) WIIW structural report: structural developments in Central and Eastern Europe. Vienna Institute for International Economic Studies, Vienna, pp 159-194

Knell M (2000) Patterns of technological activity in CEECs. In: Landesmann M (ed) WIIW structural report: structural developments in Central and Eastern Europe. Vienna Institute for International Economic Studies, Vienna, pp 195-218

Lawrence RZ, Slaughter MJ (1993) International trade and American wages: giant sucking sound or small hiccup? Brooking Papers on Economic Activity, Microeconomics 2 1993: 161-210

Pavcnik N (2003) What explains skill upgrading in less developed countries? Journal of Development Economics 71: 311-328

Resmini L (2000) The determinants of foreign direct investment in the CEECs: new evidence from sectoral patterns. Economics of Transition 8: 665-689

Roland G, Verdier T (1999) Transition and the output fall. Economics of Transition 7: 1-28

Rosati D (1994) Output decline during transition from plan to market. Economics of Transition 2: 419-442

UNCTAD (2002a) Handbook of statistics. United Nations Organization, New York

UNCTAD (2002b) World investment report. United Nations Organization, New York

Urban W (2000) Patterns of structural change in CEEC manufacturing. In: Landesmann M (ed) WIIW structural report: structural developments in Central and Eastern Europe. Vienna Institute for International Economic Studies, Vienna, pp 20-66 